\title{
Non-pharmacological measures for pain relief in venipuncture in newborns: description of behavioral and physiological responses
}

\author{
Medidas não farmacológicas para alívio da dor na punção venosa em recém-nascidos: \\ descrição das respostas comportamentais e fisiológicas
}

Priscila Pereira de Souza Gomes ${ }^{1}$, Ana Paola de Araújo Lopes², Maria Solange Nogueira dos Santos ${ }^{3}$, Silvania Moreira de Abreu Façanha $^{4}$, Ana Valeska Siebra e Silva ${ }^{5}$, Edna Maria Camelo Chaves ${ }^{5}$

\section{ABSTRACT}

BACKGROUND AND OBJECTIVES: Venipuncture is considered a painful procedure, often performed in the neonatal intensive care unit. The objective of this study is to describe the behavioral and physiological responses of newborns undergoing venipuncture, with and without the use of non-pharmacological measures for the relief of pain.

METHODS: A total of 84 newborns participated in this research. It was observed if the nurse prepared the newborn for the puncture. Newborns that did not receive the non-pharmacological approach were allocated in group 1, and those who received were to group 2. The behavioral and physiological parameters were assessed two minutes before and two minutes after the procedure in all newborns. The data analysis was descriptive.

RESULTS: Before the procedure, $45.5 \%$ of the newborns in group 1 had a contracted face; however, after the procedure, this number increased to $69.7 \%$. After the procedure in group 2, $29.4 \%$ grumbled, $3.9 \%$ had a vigorous cry, $66.7 \%$ did not cry. Arms and legs movement had similar responses in both groups. After the procedure, $72.7 \%$ of newborns in group 1 had a heart rate higher than $160 \mathrm{bpm}$. After the procedure in group 1, 15.2\% had an oxygen saturation between 96 and $100 \%$ and this value increase to $58.8 \%$ in group 2 .

\footnotetext{
Priscila Pereira de Souza Gomes - (Dhttps://orcid.org/0000-0001-8743-145X; Ana Paola de Araújo Lopes - Dhttps://orcid.org/0000-0001-5409-2543;

Maria Solange Nogueira dos Santos - Dhttps://orcid.org/0000-0002-8509-1989;

Silvânia Moreira de Abreu Façanha - (Dhttps://orcid.org/0000-0002-7853-3160;

Ana Valeska Siebra e Silva - (Dhttps://orcid.org/0000-0003-3664-5073;

Edna Maria Camelo Chaves - (Dhttps://orcid.org/0000-0001-9658-0377.
}

1. Universidade Estadual do Ceará, Programa de Pós-Graduação Cuidados Clínicos em Enfermagem e Saúde, Fortaleza, CE, Brasil.

2. Universidade Estadual do Ceará, Departamento de Enfermagem, Fortaleza, CE, Brasil.

3. Hospital Geral de Fortaleza, Fortaleza, CE, Brasil.

4. Universidade Estadual do Ceará, Mestrado Profissional em Saúde da Criança e do Ado-

lescente, Fortaleza, CE, Brasil.

5. Universidade Estadual do Ceará, Fortaleza, CE, Brasil.

Submitted on August 22, 2018.

Accepted for publication on March 22, 2019.

Conflict of interests: none - Sponsoring sources: none.

Correspondence to:

Av. Dr. Silas Munguba, 1700 - Campus do Itaperi

60741-000 Fortaleza, CE, Brasil.

E-mail: priscilaenfermagem_@hotmail.com

(C) Sociedade Brasileira para o Estudo da Dor
CONCLUSION: The behavioral and physiological responses presented by the newborns are altered when babies undergo venipuncture without the use of measures for the relief of pain, the most common being: contracted face; grumbling; arms and legs flexed/extended; tachycardia; and hyposaturation.

Keywords: Neonatal intensive care units, Newborn, Pain, Peripheral catheterization.

\section{RESUMO}

JUSTIFICATIVA E OBJETIVOS: A punção venosa é considerada um procedimento doloroso, realizado com frequência na unidade de terapia intensiva neonatal. O objetivo deste estudo foi descrever as respostas comportamentais e fisiológicas de recém-nascidos submetidos à punção venosa, com e sem a utilização de medidas não farmacológicas para alívio da dor.

MÉTODOS: Participaram da pesquisa 84 recém-nascidos. Foi observado se o profissional de enfermagem realizava o preparo do recém-nascido para a punção. Os recém-nascidos que não receberam medida náo farmacológica foram alocados no grupo 1 e os que receberam foram para o grupo 2. Foram avaliados os parâmetros comportamentais e fisiológicos dois minutos antes e dois minutos após o procedimento em todos os recém-nascidos. A análise dos dados ocorreu de forma descritiva.

RESULTADOS: Antes do procedimento, 45,5\% dos recém-nascidos no grupo 1 apresentavam a face contraída, entretanto, após o procedimento, esse número aumentou para 69,7\%. Depois do procedimento no grupo 2, 29,4\% resmungaram, 3,9\% tiveram choro vigoroso e em $66,7 \%$ o choro ficou ausente. Os movimentos de braços e pernas apresentaram respostas semelhantes nos dois grupos. Após o procedimento, 72,7\% do grupo 1 apresentaram frequência cardíaca maior que $160 \mathrm{bpm}$. Após o procedimento no grupo 1, 15,2\% apresentaram saturaçáo de oxigênio entre 96 e 100\%, já no grupo 2, esse valor aumentou para 58,8\%.

CONCLUSÃO: As respostas comportamentais e fisiológicas apresentadas pelos recém-nascidos sofrem maiores alteraçóes quando os bebês são submetidos à punção venosa sem o uso de medidas para alívio da dor, sendo as mais presentes: face contraída; resmungos; braços e pernas fletidos/estendidos; taquicardia e hipossaturação.

Descritores: Cateterismo periférico, Dor, Recém-nascido, Unidades de terapia intensiva neonatal. 


\section{INTRODUCTION}

Pain is an unpleasant sensory and emotional experience associated with a real or potential tissue injury ${ }^{1}$. Newborns (NB) admitted to a neonatal intensive care unit (NICU) are usually submitted to painful procedures, such as surgeries, venous punctures, and aspirations. However, other seemingly simple care, such as changing diapers, weighing and removing tape can also result in noxious stimuli ${ }^{2}$.

Pain is becoming increasingly important in the health area because it causes a high level of discomfort and instability that can influence the alteration of vital signs and, consequently, the hemodynamics of patients. It is essential to recognize pain as a vital data that deserves to be valued and included in the planning of the care of the individuals ${ }^{3}$.

Healthcare professionals have the responsibility to provide a systematic approach in pain management, including assessment, prevention and treatment of pain in $\mathrm{NB}^{2}$. In a study conducted with nurses of a NICU of a university hospital, professionals reported that the non-verbalization of the newborns was the greatest difficulty found to recognize and assess pain ${ }^{4}$.

Thus, the implementation of guidelines for pain control in clinical practice is not an easy task since it involves several organizational and individual factors. Caregiving practices should be based on evidence and not on tradition, routine, or individual's experiences 5 .

Both pharmacological and non-pharmacological measures are necessary to control pain. The pharmacological strategies are indicated for severe pain, usually caused by invasive, prolonged, more complex procedures, and include the use of opioids and local anesthetics, among others ${ }^{6}$.

Non-pharmacological interventions are most commonly used for acute pain, caused by minor procedures, such as venipuncture and blood collection that cause agitation and stress ${ }^{7}$. The Department of Health recommends the use of non-pharmacological measures, such as sweetened solutions (glucose or sucrose), breastfeeding, non-nutritive sucking, skin-to-skin contact, and to reduce tactile stimuli ${ }^{8}$.

The use of non-pharmacological measures, before painful procedures, is becoming a strategy of care that must be performed in newborns in hospital units. This is because the pain suffered by the NB causes organic repercussions that may compromise its development, and the pharmacological therapy presents several adverse effects due to the immaturity of the baby's organic systems'.

Oral glucose administration has been the most widely used measure in NB interventions. However, new strategies are being pointed out, such as the use of scents to promote pain relief and winding?.

A flowchart to help to handle the pain in NICUs, created by nurses, states that breastfeeding and oral breast milk supplementation need to be prioritized because it favors the mother's participation in the care of the newborn. In addition to these strategies, the flowchart also recommends the use of environmental measures such as reducing the noise, stimuli, abrupt changes in brightness and temperature ${ }^{10}$.

However, for the implementation of non-pharmacological measures to take place effectively, it is necessary to make health pro- fessionals aware of the right of the newborns to have the pain avoided and treated. They also need to know how these measures must be applied ${ }^{11}$.

To use the pain relief measures properly, it is necessary to evaluate, identify and initiate pain treatment, as these actions contribute to a faster recovery and better quality of care ${ }^{5}$.

Venipuncture is considered a painful procedure and is frequently performed in the NICU. Therefore, it is necessary to evaluate the behavioral and physiological responses of the newborns who undergo such procedure, since a reliable description of the pain experience is fundamental to identify the best treatment for each $\mathrm{NB}^{8}$.

The objective of this study was to describe the behavioral and physiological responses of newborns undergoing venipuncture, with and without the use of non-pharmacological measures for pain relief.

\section{METHODS}

This is a cross-sectional study conducted in a NICU of a tertiary referral hospital in the city of Fortaleza, CE, Brazil. The institution is a teaching hospital, accredited by the Unified Health System, which assists the mothers and children at risk.

The study evaluated the behavioral and physiological parameters of newborns subject to venipuncture. To estimate the study sample, we considered $\mathrm{n}=640$ (NB admitted in 2014), confidence level $=90 \%, \mathrm{P}=50 \%$ (pain prevalence during puncture), $\mathrm{Q}=50 \%$ (complementary percentage of $\mathrm{P}$ ), sampling error $=10 \%$. The calculation of the sample size resulted in $61 \mathrm{NB}$. However, the data was collected in $84 \mathrm{NB}$, considering the possibility of losses during the study, which did not occur. The study included those NB hospitalized in the unit during data collection, regardless of gestational age. NB under pharmacological measures for pain relief and those with congenital malformation were excluded from the study.

Data collection was from September 2015 to June 2016. The data collection instrument used was a form containing the NB identification data. The assessment of pain before and after the venipuncture used the Neonatal Infant Pain Scale (NIPS), the heart rate and oxygen saturation, and the description of the non-pharmacological measure if any.

The NIPS is a scale used to assess pain signs in the newborn. It has six pain indicators, one physiological and five behavioral, including facial expression, crying, movement of arms and legs, sleep/alertness state and respiratory pattern. The scale scores vary between zero, one and two points, depending on the characteristic presented. The minimum score is zero, and the maximum score is seven. The pain is characterized by the sum of points greater than or equal to four ${ }^{8}$.

It is noteworthy that in this unit, the multiprofessional team was trained to use non-pharmacological measures before painful procedures. Some strategies recommended are the use of oral glucose at 25\%, facilitated containment, lap, and touch.

Initially, the researchers were trained to collect data, after the approval of the research project. The data was collected in the morning and afternoon shifts. The researcher recorded whether 
the nurse or nurse technician prepared or not the newborn for the painful procedure. A damp gauze with glucose at $25 \%$ was offered two minutes before the procedure. The facilitated containment was performed two minutes before the puncture. No time was established for the newborn to stay on the mother's lap. The puncture was performed two minutes after the NB was placed in the crib. After the collection, all participants were observed for two minutes. The parameters were recorded two minutes before and two minutes after the puncture.

To better understand the data, the newborns were divided into two groups. Group 1 (G1) was comprised the NB with no non-pharmacological measures for pain relief, while group 2 (G2) was formed by the NB who received some non-pharmacological measure before the puncture.

The research complied with the standards of the Resolution $466 / 12$. The NB was included in the study after the signing of the Free and Informed Consent Term (FICT) by the person responsible for the NB. The study is part of an umbrella project and was approved by the Ethics Committee of the Institution under number $011201 / 2011$.

\section{Statistical analysis}

The data were organized in an Excel database and analyzed by the Statistical Package for Social Science (SPSS) software, version 20.0. The analysis was performed through the absolute and relative frequencies, mean frequency and standard deviation. The results were presented in tables and discussed according to relevant literature.

\section{RESULTS}

Table 1 shows the clinical variables of the newborns participating in the study.

As observed in table 1 , most of the NBs were male $(67.9 \%)$, low weight $(73.8 \%)$, c-section delivery $(73.8 \%)$ and premature (79.8\%). The mean weight was $2.067 \pm 789 \mathrm{~g}$. The mean gestational age was $34.6 \pm 3$ weeks. The leading causes of hospitalization were respiratory distress $(41.7 \%)$, prematurity $(27.4 \%)$, hypoglycemia $(8.3 \%)$, among others. The non-pharmacological measures used by the nursing team for the NB subjected to venipuncture were glucose at $25 \%(72.5 \%)$, facilitated containment (21.6\%) and lap (5.9\%).

Table 2 describes the behavioral responses of the newborns before and after the puncture.

According to table 2, of the 84 NB subjected to venipuncture, $51(60.7 \%)$ were prepared with a non-pharmacological measure for pain relief.

Regarding the behavioral responses, it is observed that before the procedure, in group 1, 45.5\% had a contracted face. However, after the procedure this number increased to $69.7 \%$. On the other hand, in group 2 , only $27.5 \%$ had a contracted face before the procedure, evolving to $33.3 \%$ afterward.

After the procedure in group 1, $81.8 \%$ of the NB grunted, and $6.1 \%$ had vigorous crying. In group 2, after the procedure, $29.4 \%$ grunted, $3.9 \%$ had vigorous crying, and crying was absent in $66.7 \%$.
Table 1. Description of variables of the newborns in the study, Fortaleza, CE

\begin{tabular}{|c|c|c|c|}
\hline Variables & $\mathrm{n}$ & $\%$ & Mean \pm SD \\
\hline $\begin{array}{l}\text { Gender } \\
\text { Male } \\
\text { Female }\end{array}$ & $\begin{array}{l}57 \\
27\end{array}$ & $\begin{array}{l}(67.9) \\
(32.1)\end{array}$ & \\
\hline $\begin{array}{l}\text { Weight (gr) } \\
\quad<2500 \\
\geq 2500\end{array}$ & $\begin{array}{l}62 \\
22\end{array}$ & $\begin{array}{l}(73.8) \\
(26.2)\end{array}$ & $2.067 \pm 789$ \\
\hline $\begin{array}{l}\text { Delivery type } \\
\text { C-section } \\
\text { Normal }\end{array}$ & $\begin{array}{l}62 \\
22\end{array}$ & $\begin{array}{l}(73.8) \\
(26.2)\end{array}$ & \\
\hline $\begin{array}{l}\text { Gestational age (weeks) } \\
<37 \\
\text { Between } 37 \text { and } 41 \\
\geq 42\end{array}$ & $\begin{array}{c}67 \\
17 \\
0\end{array}$ & $\begin{array}{c}(79.8) \\
(20.2) \\
0\end{array}$ & $34.6 \pm 3$ \\
\hline $\begin{array}{l}\text { Diagnosis } \\
\text { Respiratory distress } \\
\text { Premature } \\
\text { Hypoglycemia }\end{array}$ & $\begin{array}{c}35 \\
23 \\
7\end{array}$ & $\begin{array}{c}(41.7) \\
(27.4) \\
(8.3)\end{array}$ & \\
\hline Sepsis & 5 & (5.9) & \\
\hline Jaundice & 4 & $(4.8)$ & \\
\hline Neonatal infection & 3 & (3.6) & \\
\hline Congenital syphilis & 2 & (2.4) & \\
\hline Others & 5 & (5.9) & \\
\hline $\begin{array}{l}\text { Non-pharmacological m } \\
\text { Glucose at } 25 \% \\
\text { Facilitated contention } \\
\text { Lap }\end{array}$ & $\begin{array}{c}37 \\
11 \\
3\end{array}$ & $\begin{array}{c}(72.5) \\
(21.6) \\
(5.9)\end{array}$ & \\
\hline
\end{tabular}

Source: Elaborated by the authors.

Table 2. Description of the behavioral responses of the newborns subjected to venipuncture, with and without non-pharmacological measures, Fortaleza, CE

\begin{tabular}{|c|c|c|c|c|}
\hline \multirow{2}{*}{$\begin{array}{l}\text { Behavioral parameters } \\
\text { at venipuncture }\end{array}$} & \multicolumn{2}{|c|}{$\mathrm{G} 1(\mathrm{n}=33)$} & \multicolumn{2}{|c|}{$\mathrm{G} 2(\mathrm{n}=51)$} \\
\hline & $\begin{array}{l}\text { Before } \\
\text { n \% }\end{array}$ & $\begin{array}{l}\text { After } \\
\mathrm{n} \%\end{array}$ & $\begin{array}{c}\text { Before } \\
\mathrm{n} \%\end{array}$ & $\begin{array}{l}\text { After } \\
\mathrm{n} \%\end{array}$ \\
\hline \multicolumn{5}{|l|}{ Facial Expression } \\
\hline Relaxed & $18(54.5)$ & $10(30.3)$ & $37(72.5)$ & $34(66.7)$ \\
\hline Contracted & $15(45.5)$ & $23(69.7)$ & $14(27.5)$ & $17(33.3)$ \\
\hline \multicolumn{5}{|l|}{ Crying } \\
\hline Absent & $19(57.6)$ & $4(12.1)$ & $39(76.5)$ & $34(66.7)$ \\
\hline Grumble & $13(39.4)$ & $27(81.8)$ & $9(17.6)$ & $15(29.4)$ \\
\hline Vigorous & $1(3)$ & $2(6.1)$ & $3(5.9)$ & $2(3.9)$ \\
\hline \multicolumn{5}{|l|}{ Breathing } \\
\hline Relaxed & $17(51.5)$ & $13(39.4)$ & $42(82.4)$ & $40(78.4)$ \\
\hline Altered & $16(48.5)$ & $20(60.6)$ & $9(17.6)$ & $11(21.6)$ \\
\hline \multicolumn{5}{|l|}{ Arms } \\
\hline Relaxed & $12(36.4)$ & $9(27.3)$ & $35(68.6)$ & $33(64.7)$ \\
\hline Flexed / extended & $21(63.6)$ & $24(72.7)$ & $16(31.4)$ & $18(35.3)$ \\
\hline \multicolumn{5}{|l|}{ Legs } \\
\hline Relaxed & $12(36.4)$ & $10(30.3)$ & $34(66.7)$ & $32(62.7)$ \\
\hline Flexed / extended & $21(63.6)$ & $23(69.7)$ & $17(33.3)$ & $19(37.3)$ \\
\hline \multicolumn{5}{|l|}{ Conscious state } \\
\hline Sleeping / quiet & $18(54.5)$ & $13(39.4)$ & $45(88.2)$ & $41(80.4)$ \\
\hline Uncomfortable & $15(45.5)$ & $20(60.6)$ & $6(11.8)$ & $10(19.6)$ \\
\hline
\end{tabular}


Regarding the movement of the limbs, the arms and legs showed similar responses when the newborns were subjected to the venipuncture. After the procedure in group 1, 72.7\% of the NB had their arms flexed/extended. However, after the procedure in group 2, it was observed that the arms were flexed/extended in $35.3 \%$ of the NB. Regarding the legs, $69.7 \%$ of the newborns in group 1 remained with the lower limbs flexed/extended after the procedure, and in group 2, the same was observed in $37.3 \%$ of the newborns.

The NB showed an uncomfortable state of consciousness in $60.6 \%$ of the cases, after the puncture in group 1 . On the other hand, discomfort was observed in only $19.6 \%$ of the NB in group 2 .

Breathing is a physiological manifestation; however, because it is part of NIPS, it was checked at that time. Thus, it is possible to state that $39.4 \%$ of the NB in group 1 had relaxed breathing after the procedure, and $78.4 \%$ had the same after the procedure in group 2 .

Table 3 shows the heart rate and oxygen saturation of NB subjected to venipuncture. Thus, one can notice that $72.7 \%$ of the $\mathrm{NB}$ in group 1 had a heart rate higher than 160bpm (tachycardia), after the procedure. On the other hand, $35.3 \%$ of the NB in group 2 had tachycardia.

After the procedure in group 1, only $15.2 \%$ of the NB had oxygen saturation between 96 and 100\%; in group 2, this value increased to $58.8 \%$.

Table 3. Description of the physiological responses of the newborns subjected to venipuncture, with and without non-pharmacological measures, Fortaleza, CE

\begin{tabular}{lcccc}
\hline $\begin{array}{l}\text { Physiological parame- } \\
\text { ters at venipuncture }\end{array}$ & \multicolumn{2}{c}{$\mathrm{G} 1(\mathrm{n}=33)$} & \multicolumn{2}{c}{$\mathrm{G} 2(\mathrm{n}=51)$} \\
$\mathrm{Before}$ & $\mathrm{n} \%$ & $\begin{array}{c}\text { After } \\
\mathrm{n} \%\end{array}$ & $\begin{array}{c}\text { Before } \\
\mathrm{n} \%\end{array}$ & $\begin{array}{c}\text { After } \\
\mathrm{n} \%\end{array}$ \\
\hline $\begin{array}{l}\text { Heart rate (bpm) } \\
100-119\end{array}$ & - & $1(3)$ & - & $3(5.9)$ \\
$120-139$ & $8(24.2)$ & $3(9.1)$ & $11(21.6)$ & $9(17.6)$ \\
$140-159$ & $23(69.7)$ & $5(15.2)$ & 3160.8 & $21(41.2)$ \\
$\geq 160$ & $2(6.1)$ & $24(72.7)$ & $9(17.6)$ & $18(35.3)$ \\
Oxygen saturation (\%) & & & & \\
$81-85$ & - & - & - & - \\
$86-90$ & $1(3)$ & $18(54.5)$ & - & $10(19.6)$ \\
$91-95$ & $10(30.3)$ & $10(30.3)$ & $11(21.6)$ & $11(21.6)$ \\
$\quad 96-100$ & $22(66.7)$ & $5(15.2)$ & $40(78.4)$ & $30(58.8)$ \\
\hline Source: Elaborated by the authors. & & &
\end{tabular}

\section{DISCUSSION}

Among the invasive procedures performed in NICUs, venipuncture is one of those with the highest percentage of moderate and severe pain ${ }^{12}$. Therefore, it is essential that health professionals use measures that help to control or reduce pain in the NB subjected to venipuncture. The results of the study showed that more than half of the NB had venipuncture and were prepared for the procedure with non-pharmacological measures for pain relief. This finding is the opposite of what was found in a study to assess the pain in NB during peripheral and capillary puncture, in which nurses used non-pharmacological measures in NB who had already presented pain ${ }^{13}$. The absence of pain relief measures in the other punctures performed may be because there is no systematization of the procedures performed at the institution since the use of pharmacological, behavioral and environmental analgesic strategies is still inconsistent in Brazil ${ }^{14}$. Thus, it is necessary to implement guidelines and protocols in health institutions for the appropriate management of pain in NB in NICUs, considering that this population is constantly subjected to stressful and painful procedures ${ }^{14}$.

The organization, preparation of the material, the agility of the nursing professional at the moment of the puncture and the concern with the number of puncture attempts on the $\mathrm{NB}$ are measures that contribute to optimize the procedure and, therefore, reduce the pain. However, it is important to avoid the negative effects of the procedure using strategies to control the pain, such as non-pharmacological measures ${ }^{12}$. In the present study, the non-pharmacological measure mostly used for pain relief was glucose at $25 \%$, followed by facilitated containment and lap. In a study performed with 110 NB submitted to venous and capillary puncture, the result was similar because glucose at $25 \%$ became the most used measure, also being mentioned coziness, therapeutic touch, and massage ${ }^{13}$.

Studies have been conducted to evaluate the efficacy of non-pharmacological measures for pain relief. It is important to emphasize an investigation conducted in Turkey about the effect of breastfeeding and sucrose in newborns submitted to venipuncture. In such an approach, it was shown that the mean NIPS score in the control group was significantly higher than in the breastfeeding and sucrose groups ${ }^{15}$. Another study conducted in Joâo Pessoa-PB found that the use of non-pharmacological measures (contention and non-nutritive suction) were able to reduce pain in the observed $\mathrm{NB}^{16}$.

The use of NIPS to assess pain in newborns is recommended because the specific scales for newborns usually provide better knowledge about the subject, minimizing the insecurity of the professional and helping the team in the identification, evaluation, and application of measures for the relief and treatment of pain ${ }^{17}$.

Regarding the responses presented, according to the NIPS, the study showed that after the procedure, the NB who did not receive any preparation had a higher percentual of the contracted face when compared to those who received. This result is similar to a study in which $32 \mathrm{NB}$ undergoing venipuncture showed suggestive signs of pain, and 100\% had a contracted face ${ }^{13}$. In another study conducted with $29 \mathrm{NB}$, among those who showed suggestive signs of pain, the contracted face was described in $77.8 \%{ }^{18}$.

As for crying, most of the NB who did not receive the measures presented grunts and vigorous crying. This data is in line with the results of a study that showed grunts $(44.4 \%)$ and vigorous crying (44.4\%) as suggestive signs of pain after puncture ${ }^{18}$. Another study reports that the mean crying 
time was higher in the control group than in the groups that received the non-pharmacological measures for pain relief ${ }^{15}$. However, although very present, the crying observed in the form of grunts, both in the NB who received the preparation measures and in those who did not, should not be considered an isolated factor to identify the presence of pain, since it can be triggered by other stimuli, like sleep and hunger ${ }^{19}$.

The movement of the arms and legs was similar, with a higher percentage of NB with relaxed limbs after the procedure when non-pharmacological measures were used, in comparison to the ones that did not have preparation. This finding corroborates the results of a study also conducted in Fortaleza, where the movements of the arms were practically the same as those observed in the movements of the legs ${ }^{13}$. A study recommends that to make the assessment of pain more reliable, it is important to evaluate the motor activity with other indicators ${ }^{20}$, which reinforces the use of scales for pain analysis.

As for the state of consciousness, the NB who received the non-pharmacological measures were considerably calmer after the procedure than those who did not receive. A study developed with 26 nursing professionals found a similar result in which the interviewed professionals reported that after the use of non-pharmacological measures, newborns were much calmer and in better conditions for the procedure, reducing the period of exposure to painful stimulus ${ }^{20}$.

Regarding breathing, the NB who went through the preparation measures had relaxed breathing, for the most part. A survey showed that among the $\mathrm{NB}$ who felt pain, the breathing in $88.9 \%$ was different from the baseline ${ }^{18}$. The alteration of the respiratory rate was one of the characteristics mentioned by health professionals to identify pain, even when they haven't heard about the validated scales for this purpose ${ }^{20}$.

In the present study, it was observed a variation in the heart rate, especially for higher values, in the NB who did not receive preparation with the non-pharmacological measures. This result differs from what was found in research about the use of sucrose and breastfeeding for pain relief in NB subjected to venipuncture, where there was no difference in the mean heart rate before, during and after the procedure, even with the use of non-pharmacological measures for the relief of pain ${ }^{15}$.

Finally, it was observed a decrease in oxygen saturation after the procedure, both in the NB who received non-pharmacological measures and those who did not. However, the NB who did not receive preparation had a higher percentage of decrease in oxygen saturation. This is in line with the results of another study, in which the mean level of oxygen saturation after the procedure was significantly higher in the NB who received the preparation than in those who did not ${ }^{15}$.
As a limitation of the results of the study is the fact that the cross-sectional design does not allow to establish the relationship between cause and effect.

\section{CONCLUSION}

The behavioral and physiological responses presented by the NB were significantly altered when they were submitted to venipuncture without the use of measures for pain relief. The most frequent responses were contracted face, grunts, arms and legs flexed/extended, tachycardia and hyposaturation.

\section{REFERENCES}

1. IASP. International Association for the Study of Pain. Pain terms: a list with definitions and notes on usage. Recommended by the IASP Subcommittee on Taxonomy. Pain. 1979;6(3):249-52.

2. Krishnan L. Pain relief in neonates. J Neonatal Surg. 2013;2(2):19.

3. Araújo LC, Romero B. Dor: avaliação do $5^{\circ}$ sinal vital. Uma reflexão teórica. Rev Dor. 2015;16(4):291-6.

4. Costa KF, Alves VH, Dames LJ, Rodrigues DP, Barbosa MT, Souza RR. Clinical management of pain in the newborn: perception of nurses from the neonatal intensive care unit. J Res Fundam Care. 2016;8(1):3758-69.

5. Christoffel MM, Castral TC, Daré MF, Montanholi LL, Gomes AL, Scochi CG. Atitudes dos profissionais de saúde na avaliaçâao e tratamento da dor neonatal. Esc Anna Nery. 2017;21(1):1-8.

6. Oliveira RM, Silva AV, Silva LM, Silva AP, Chaves EM, Bezerra SC. Implementação de medidas para o alívio da dor em neonatos pela equipe de enfermagem. Esc Anna Nery. 2011;15(2):277-83.

7. Amaral JB, Resende TA, Contim D, Barichello E. Equipe de enfermagem diante da dor do recém-nascido pré-termo. Esc Anna Nery. 2014;18(2):241-6.

8. Brasil. Ministério da Saúde. Atençấo à Saúde do Recém-nascido: guias para o profissional de saúde. Brasília: Ministério da Saúde; 2011.

9. Morais AP, Façanha SM, Rabelo SN, Silva AV, Queiroz MV, Chaves EM. Medidas não farmacológicas no manejo da dor em recém-nascidos: cuidado de enfermagem. Rev Rene. 2016;17(3):435-42.

10. Querido DL, Christoffel MM, Almeida VS, Esteves AP, Andrade M, Amim Junior J Fluxograma assistencial para manejo da dor em Unidade de Terapia Intensiva Neonatal. Rev Bras Enferm. 2018;71(Suppl3):1360-9.

11. Leite AM, Silva AC, Castral TC, Nascimento LC, Sousa MI, Scohi CG. Amamentação e contato pele-a-pele no alívio da dor em recém-nascidos na vacina contra hepatite B. Rev Eletr Enf. 2015;17(3):1-8.

12. Cruz CT, Gomes JS, Kirchner RM, Stumm EM. Evaluation of pain of neonates during invasive procedures in intensive care. Rev Dor. 2016;17(3):197-200.

13. Morais AP, Dodt RC, Farias LM, Melo GM, Muniz Filha MJ, Chaves EM. Dimensionamento da dor em recém-nascido durante punção venosa periférica e capilar. Rev Enferm UFPE. 2013;7(2):511-7.

14. Costa P, Bueno M, Oliva CL, Elci de Castro T, Ponce de Camargo P, Kimura AF. [Analgesia and sedation during placement of peripherally inserted central catheters in neonates]. Rev Esc Enferm USP. 2013;47(4):801-7. Portuguese.

15. Efe E, Savaser $S$. The effect of two different methods used during peripheral venous blood collection on pain reduction in neonates. Agri. 2007;19(2):49-56.

16. Santos GC, Lima LM, Oliveira GB, Souza AR, Freitas VS. Intervenção de Enfermagem no controle da dor em neonato: eficácia de açōes não farmacológicas. Rev Enferm UFPE. 2015;9(8):8784-91.

17. Araújo GC, Miranda JO, Santos DV, Camargo CL, Sobrinho CL, Rosa DO. Dor em recém-nascidos: identificaçấo, avaliaçâo e intervençôes. Rev Baiana Enferm. 2015;29(3):261-70.

18. Santos LM, Silva TP, Santana RC, Matos KK. Sinais sugestivos de dor durante a punçăo venosa periférica em prematuros. Rev Enferm UFSM. 2012;2(1):1-9.

19. Santos LM, Ribeiro IS, Santana RC. Identificação e tratamento da dor no recém-nascido prematuro na Unidade de Terapia Intensiva. Rev Bras Enferm. 2012;65(2):269-75.

20. Costa LC, Souza MG, Sena EM, Mascarenhas ML, Moreira RT, Lúcio IM. Utilização de medidas năo farmacológicas pela equipe de enfermagem para alívio da dor neonatal. Rev Enferm UFPE. 2016;10(7):2395-403. 